\title{
FORTY-THIRD ANNUAL LIST OF PAPERS
}

READ BEFORE THE AMERICAN MATHEMATICAL SOCIETY AND SUBSEQUENTLY PUBLISHED, INCLUDING REFERENCES TO THE PLACES OF PUBLICATION

Adams, C. R., and Clarkson, J. A. On convergence in variation. Read Dec. 27, 1933. This Bulletin, vol. 40, No. 6, pp. 413-417; June, 1934.

- Properties of functions $f(x, y)$ of bounded variation. Read Dec. 27, 1933. Transactions of this Society, vol. 36, No. 4, pp. 711-730; Oct., 1934.

Agnew, R. P. On summability of multiple sequences. Read Oct. 28, 1933. American Journal of Mathematics, vol. 56, No. 1, pp. 62-68; Jan., 1934.

Albert, A. A. On universal sets of positive ternary quadratic forms. Read April 15, 1933. Annals of Mathematics, (2), vol. 34, No. 4, pp. 875-878; Oct., 1933.

Normal division algebras of degree 4 over $F$ of characteristic 2 . Read Dec. 1, 1933. American Journal of Mathematics, vol. 56, No. 1, pp. 75-86; Jan., 1934.

- On the construction of Riemann matrices. I. Read Feb. 28, 1931. Annals of Mathematics, (2), vol. 35, No. 1, pp. 1-28; Jan., 1934.

- On a certain algebra of quantum mechanics. Read Dec. 27, 1933. Annals of Mathematics, (2), vol. 35, No. 1, pp. 65-73; Jan., 1934.

Integral domains of rational generalized quaternion algebras. Read June 19, 1933. This Bulletin, vol. 40, No. 2, pp. 164-176; Feb., 1934.

- On certain imprimitive fields of degree $p^{2}$ over $P$ of characteristic $p$. Read Dec. 1, 1933. Annals of Mathematics, (2), vol. 35, No. 2, pp. 211-219; April, 1934.

_ Normal division algebras over a modular field. Read Dec. 1, 1933. Transactions of this Society, vol. 36, No. 2, pp. 388-394; April, 1934.

- $A$ solution of the principal problem in the theory of Riemann matrices. Read March 30, 1934. Annals of Mathematics, (2), vol. 35, No. 3, pp. 500-515; July, 1934.

Cyclic fields of degree $p^{n}$ over $F$ of characteristic $p$. Read March 30, 1934. This Bulletin, vol. 40, No. 8, pp. 625-631; Aug., 1934.

- On normal Kummer fields over a non-modular field. Read Dec. 27, 1933. Transactions of this Society, vol. 36, No. 4, pp. 885-892; Oct., 1934.

- The principal matrices of a Riemann matrix. Read Sept. 7, 1934. This Bulletin, vol. 40, No. 12, pp. 843-846; Dec., 1934.

Alden, H. H. Solution of $f(x, y) \partial z / \partial x+g(x, y) \partial z / \partial y=0$ in a neighborhood of $a$ singular point. Read April 15, 1933. American Journal of Mathematics, vol. 56, No. 4, pp. 593-612; Oct., 1934.

Altshiller-Court, N. On the Apollonian spheres of a tetrahedron. Read Sept. 2, 1932. Tôhoku Mathematical Journal, vol. 39, No. 2, pp. 264-268; June, 1934.

Bacon, H. M. An extension of Kronecker's theorem. Read Aug. 31, 1932. Annals of Mathematics, (2), vol. 35, No. 4, pp. 776-786; Oct., 1934.

Baten, W. D. The probability law for the sum of $n$ independent variables, each subject to the law $(1 /(2 h))$ sech $(\pi x /(2 h))$. Read June 22,1933 . This Bulletin, vol. 40, No. 4, pp. 284-290; April, 1934. 
Beckenbach, E. F. A characteristic property of surfaces of negative curvature. Read April 7, 1934. This Bulletin, vol. 40, No. 10, pp. 761-768; Oct., 1934.

Bell, C. Alternant surfaces. Read Sept. 2, 1932. American Journal of Mathematics, vol. 56, No. 1, pp. 42-46; Jan., 1934.

- On some properties of polygons related to the cuspidal cubic. Read Sept. 2, 1932. Tôhoku Mathematical Journal, vol. 39, No. 2, pp. 243-247; June, 1934.

Bell, E. T. Exponential polynomials. Read Dec. 2,1933. Annals of Mathematics, (2), vol. 35, No. 2, pp. 258-277; April, 1934.

- Exponential numbers. Read Oct. 28, 1933. American Mathematical Monthly, vol. 41, No. 7, pp. 411-419; Aug.-Sept., 1934.

- On the power series for elliptic functions. Read Sept. 7, 1934. Transactions of this Society, vol. 36, No. 4, pp. 841-852; Oct., 1934.

Bernstein, B. A. A set of four postulates for Boolean algebra in terms of the "implicative" operation. Read June 19, 1933. Transactions of this Society, vol. 36, No. 4, pp. 876-884; Oct., 1934.

Birkhoff, G. Hausdorff groupoids. Read Dec. 27, 1933. Annals of Mathematics, (2), vol. 35, No. 2, pp. 351-360; April, 1934.

- On the lattice theory of ideals. Read March 30, 1934. This Bulletin, vol. 40, No. 8, pp. 613-619; Aug., 1934.

- The topology of transformation-sets. Read Dec. 27, 1933. Annals of Mathematics, (2), vol. 35, No. 4, pp. 861-875; Oct. 1934.

Transfinite subgroup series. Read Sept. 7, 1934. This Bulletin, vol. 40, No. 12, pp. 847-850; Dec., 1934.

Black, A. Types of involutorial space transformations associated with certain rational curves-composite basis curves. Read April 14, 1933. This Bulletin, vol. 40, No. 6, pp. 417-420; June, 1934.

Blichfeldt, H. F. The minimum values of positive quadratic forms in six, seven and eight variables. Read Oct. 31, 1925. Mathematische Zeitschrift, vol. 39, No. 1, pp. 1-15; July, 1934.

Blumenthal, L. M. A chain of determinant theorems arising from the characterization of pseudo r-spheric $\left(S_{n}\right)$ sets. Read Dec. 27, 1933. American Journal of Mathematics, vol. 56, No. 2, pp. 225-232; April, 1934.

Bochner, S., and Bohnenblust, H. F. Analytic functions with almost periodic coefficients. Read Dec. 27, 1933. Annals of Mathematics, (2), vol. 35, No. 1, pp. 152-161; Jan., 1934.

Bohnenblust, H. F. See Bochner, S.

Bower, O. K. Applications of an abstract existence theorem to both differential and difference equations. Read Aug. 31, 1932. Annals of Mathematics, (2), vol. 35, No. 4, pp. 748-758; Oct., 1934.

Brahana, H. R. On the isomorphisms of the abelian group of type $1,1, \cdots$. Read Oct. 28, 1933. American Journal of Mathematics, vol. 56, No.1, pp. 53-61: Jan., 1934.

- On the metabelian groups which contain a given group $H$ as a maximal invariant abelian subgroup. Read Oct. 28, 1933. American Journal of Mathematics, vol. 56, No. 4, pp. 490-512; Oct., 1934.

- Metabelian groups of order $p^{n+m}$ with commutator subgroups of order $p^{m}$. 
Read April 6, 1934. Transactions of this Society, vol. 36, No. 4, pp. 776792 ; Oct., 1934.

Brandner, F. A. A test of the significance of the difference of the correlation coefficients in normal bivariate samples. Read Nov. 25, 1932. Biometrika, vol. 25, Nos. 1-2, pp. 102-109; May, 1933.

Brown, A. B. Note on the form of a first-order partial differential equation. Read March 31, 1934. This Bulletin, vol. 40, No. 6, pp. 475-477; June, 1934.

Brown, A. B., and Koopman, B. O. The Riemann multiple-space and algebroid functions. Read May 7, 1927, and Oct. 28, 1933. Transactions of this Society, vol. 36, No. 3, pp. 618-626; July, 1934.

Cairns, S. S. On the triangulation of regular loci. Read Oct. 29, 1932, and April 14, 1933. Annals of Mathematics, (2), vol. 35, No. 3, pp. 579-587; July, 1934.

Cameron, R. H. Almost periodic transformations. Read Dec. 29, 1932, and April 14, 1933. Transactions of this Society, vol. 36, No. 2, pp. 276-291; April, 1934.

- Implicit functions of almost periodic functions. Read Oct. 28 and Dec. 1, 1933. This Bulletin, vol. 40, No. 12, pp. 895-904; Dec., 1934.

Camp, C. C. A new method for finding the numerical sum of an infinite series. Read April 8, 1932. American Mathematical Monthly, vol. 40, No. 9, pp. 537-542; Nov., 1933.

Campbell, J. W. The clock problem in relativity. (Second paper.) Read June 23, 1933. Philosophical Magazine, (7), vol. 16, No. 106, pp. 529-544; Sept., 1933

Carlitz, L. On polynomials in a Galois field: some formulae involving divisor functions. Read March 25, 1932. Proceedings of the London Mathematical Society, (2), vol. 38, No. 2, pp. 116-124; Oct., 1934.

Carmichael, R. D. Functions of exponential type. Read Dec. 1, 1933. This Bulletin, vol. 40, No. 4, pp. 241-261; April, 1934.

Carroll-Rusk, E. Cremona involutions defined by a pencil of cubic surfaces. Read Dec. 29, 1932. American Journal of Mathematics, vol. 56, No. 1, pp. 96108; Jan., 1934.

Cauer, W. Ein Interpolationsproblem mit Funktionen mit positiven Realteil. Read Feb. 28, 1931. Mathematische Zeitschrift, vol. 38, No. 1, pp. 1-44; Nov., 1933.

Church, A. A set of postulates for the foundation of logic. (Second paper.) Read Sept. 2, 1932. Annals of Mathematics, (2), vol. 34, No. 4, pp. 839-864; Oct., 1933.

Clarkson, J. A. See Adams, C. R.

Clarkson, J. M. An involutorial line transformation. Read Oct. 28, 1933. This Bulletin, vol. 40, No. 6, pp. 421-424; June, 1934.

Clarkson, J. M., and Snyder, V. An involutorial line transformation determined by a bilinear congruence of twisted elliptic quartic curves. Read March 30, 1934. This Bulletin, vol. 40, No. 6, pp. 441-448; June, 1934.

Claytor, S. Topological immersion of Peanian continua in a spherical surface. Read April 14, 1933. Annals of Mathematics, (2), vol. 35, No. 4, pp. 809835; Oct., 1934. 
Coble, A. B. Cremona diophantine equations. Read March 30, 1934. American Journal of Mathematics, vol. 56, No. 4, pp. 459-489; Oct., 1934.

Coe, C. J. Displacements of a rigid body. Read Sept. 11, 1931. American Mathematical Monthly, vol. 41, No. 4, pp. 242-253; April, 1934.

Cohen, L. W. Lagrange multipliers for functions of infinitely many variables. Read Dec. 27, 1933. This Bulletin, vol. 40, No. 4, pp. 267-270; April, 1934.

Collins, J. V. The $(r, x)$ system of coordinates and its place in analytic geometry and calculus. Read April 14, 1933. Menasha, Wis., The Collegiate Press, $1934.6+30 \mathrm{pp}$.

Conwell, H. H. Linear associative algebras of infinite order whose elements satisfy finite algebraic equations. Read April 9, 1932. This Bulletin, vol. 40, No. 2, pp. 95-102; Feb., 1934.

Coolidge, J. L. The rise and fall of projective geometry. Read Dec. 29, 1933. American Mathematical Monthly, vol. 41, No. 4, pp. 217-228; April, 1934.

Cope, F. T. Formal solutions of irregular linear differential equations. Part I. Read Dec. 27, 1932. American Journal of Mathematics, vol. 56, No. 3, pp. 411-437; July, 1934.

Copeland, A. H. A matrix theory of measurement. Read Sept. 11, 1930. Mathematische Zeitschrift, vol. 37, No. 4, pp. 542-555; Sept., 1933.

Craig, A. T. Note on the moments of a Bernoulli distribution. Read Dec. 27, 1933. This Bulletin, vol. 40, No. 4, pp. 262-264; April, 1934.

Crathorne, A. R. Moments de la binomiale par rapport à l'origine. Read April 7, 1934. Comptes Rendus, vol. 198, No. 13, p. 1202; March 26, 1934.

Curry, H. B. Some properties of equality and implication in combinatory logic. Read Sept. 2, 1932. Annals of Mathematics, (2), vol. 35, No. 4, pp. 849860 ; Oct., 1934.

Davis, H. T. Polynomial approximation by the method of least squares. Read Nov. 27, 1931. Annals of Mathematical Statistics, vol. 4, No. 3, pp. 155195; Aug., 1933.

Dickson, L. E. Waring's problem for cubic functions. Read June 19, 1933. Transactions of this Society, vol. 36, No. 1, pp. 1-12; Jan., 1934.

- Waring's problem for ninth powers. Read April 7, 1934. This Bulletin, vol. 40, No. 6, pp. 487-493; June, 1934. Universal Waring theorem for eleventh powers. Read April 7, 1934. Journal of the London Mathematical Society, vol. 9, No. 3, pp. 201-206; July, 1934.

- A new method for Waring theorems with polynomial summands. Read April 7, 1934. Transactions of this Society, vol. 36, No. 4, pp. 731-748; Oct., 1934.

Dines, L. L., and McCoy, N. H. On linear inequalities. Read Sept. 8, 1931. Transactions of the Royal Society of Canada, (3), vol. 27, Section III, pp. 37-70; May, 1933.

Dodd, E. L. The complete independence of certain properties of means. Read Oct. 28, 1933. Annals of Mathematics, (2), vol. 35, No. 4, pp. 740-747; Oct., 1934.

Doob, J. L. Probability and statistics. Read March 31, 1934. Transactions of this Society, vol. 36, No. 4, pp. 759-775; Oct., 1934. 
Duncan, D. C. Symmetric, self-dual, rational plane curves of odd order. Read Dec. 2, 1933. This Bulletin, vol. 40, No. 4, pp. 344-352; April, 1934.

Dye, L. A., and Sharpe, F. R. The Bertini transformation in space. Read Dec. 27, 1933. Transactions of this Society, vol. 36, No. 2, pp. 292-305; April, 1934.

Eiesland, J. The ruled $V_{4}^{4}$ in $S_{5}$ associated with a Schläfi hexad. Read April 4, 1931. Transactions of this Society, vol.36, No. 2, pp. 315-326; April, 1934.

Emch, A. Ueber eine bemerkenswerte Klasse von Raumkurven sechster Ordnung vom Geschlecht 4. Read Dec. 1, 1933. Commentarii Mathematici Helvetici, vol. 7, No. 1, pp. 1-13; Sept., 1934.

Farrell, O. J. On approximation to an analytic function by polynomials. Read March 31, 1934. This Bulletin, vol. 40, No. 12, pp. 908-914; Dec., 1934.

Franklin, P. Regions of positive and negative curvature on closed surfaces. Read April 3, 1931. Journal of Mathematics and Physics, Massachusetts Institure of Technology, vol. 13, No. 2, pp. 253-260; May, 1934.

Garver, R. The Edgeworth taxation phenomenon. Read Sept. 2, 1932. Econometrica, vol. 1, No. 4, pp. 402-407; Oct., 1933.

- Note concerning group postulates. Read June 20, 1934. This Bulletin, vol. 40, No. 10, pp. 698-701; Oct., 1934.

Ghent, K.S. A note on nilpotent algebras in four units. Read Oct. 28, 1933. This Bulletin, vol. 40, No. 4, pp. 331-338; April, 1934.

Gore, G. D. Inscribed sequences of surfaces associated with generalized sequences of Laplace. Read April 7, 1934. Transactions of this Society, vol. 36, No. 3, pp. 530-541; July, 1934.

Grant, H. S. Concerning powers of certain classes of ideals in a cyclotomic realm which give the principal class. Read April 14, 1933. Annals of Mathematics, (2), vol. 35, No. 2, pp. 220-238; April, 1934.

Graustein, W. C. The geometry of Riemannian spaces. Read June 21, 1933. Transactions of this Society, vol. 36, No. 3, pp. 542-585; July, 1934.

Grove, V. G. On a certain correspondence between surfaces in hyperspace. Read April 7, 1934. Transactions of this Society, vol. 36, No. 3, pp. 627-636; July, 1934.

Halperin, M. Kasner's convex curves. Read Feb. 25, 1933. This Bulletin, vol. 40, No. 6, pp. 435-440; June, 1934.

Hanson, E. H. A new proof of a theorem of Denjoy, Young, and Saks. Read Dec. 2, 1933. This Bulletin, vol. 40, No. 10, pp. 691-694; Oct., 1934.

Haviland, E. K. On the theory of absolutely additive distribution functions. Read March 31, 1934. American Journal of Mathematics, vol. 56, No. 4, pp. 625-658; Oct., 1934.

Hedlund, G. A. On the metrucal transitivity of the geodesics on a surface of constant negative curvature. Read March 31, 1934. Proceedings of the National Academy of Sciences, vol. 20, No. 2, pp. 136-140; Feb., 1934.

- On the metrical transitivity of the geodesics on closed surfaces of constant negative curvature. Read Dec. 27, 1933. Annals of Mathematics, (2), vol. 35, No. 4, pp. 787-808; Oct., 1934.

Hestenes, M. R. A note on the Jacobi condition for parametric problems in the calculus of variations. Read June 23, 1.933. This Bulletin, vol. 40, No. 4, pp. 297-302; April, 1934.

- Sufficient conditions for the problem of Bolza in the calculus of variations. 
Read June 23, 1933, and March 31, 1934. Transactions of this Society, vol. 36, No. 4, pp. 793-818; Oct., 1934.

Hightower, R. U. On the classification of the elements of a ring. Read Sept. 6, 1928. (Dissertation, Missouri.) Lancaster, Pa., the author, no date. $21 \mathrm{pp.}$ Hildebrandt, T. H. On bounded linear functional operations. Read April 7, 1934. Transactions of this Society, vol. 36, No. 4, pp. 868-875; Oct., 1934.

Hille, E., and Tamarkin, J. D. On the theory of Laplace integrals. II. Read Dec. 27, 1933. Proceedings of the National Academy of Sciences, vol. 20, No. 2, pp. 140-144; Feb., 1934.

- On the summability of Fourier series. Fifth note. Read April 15, 1933. Proceedings of the National Academy of Sciences, vol. 20, No. 6, pp. 369372; June, 1934.

Hinrichsen, J. J. L. On the problem of $n$ bodies. Read Dec. 30, 1929. Transactions of this Society, vol. 36, No. 2, pp. 306-314; April, 1934.

Hodge, W. V. D. A Dirichlet problem for harmonic functionals, with applications to analytic varieties. Read March 26, 1932. Proceedings of the London Mathematical Society, (2), vol. 36, No. 4, pp. 257-303; Nov., 1933.

Hopf, E. On causality, statistics and probability. Read Dec. 27, 1933. Journal of Mathematics and Physics, Massachusetts Institute of Technology, vol. 13, No. 1, pp. 51-102; Feb., 1934.

Hotelling, H. Analysis of a complex of statistical variables into principal components. Read Oct. 29, 1932. Journal of Educational Psychology, vol. 24, Nos. 6 and 7, pp. 417-441, 498-520; Sept. and Oct., 1933.

Huntington, E. V. Independent postulates for the "informal" part of Principia Mathematica. Read June 19, 1933. This Bulletin, vol. 40, No. 2, pp. 127136; Feb., 1934.

— Independent postulates for an "informal Principia system with equality." Read Dec. 27, 1933. This Bulletin, vol. 40, No. 2, pp. 137-142; Feb., 1934. The relation between Lewis's strict implication and Boolean algebra. Read June 20, 1934. This Bulletin, vol. 40, No. 10, pp. 729-735; Oct., 1934.

Ingraham, M. H. On the rational solutions of the matric equation $P(X)=A$. Read April 15, 1933. Journal of Mathematics and Physics, Massachusetts Institute of Technology, vol. 13, No. 1, pp. 46-50; Feb., 1934.

Ingram, W. H. On the dynamical theory of electrical commutator machines. Read Dec. 26, 1933. Proceedings of the National Academy of Sciences, vol. 20, No. 1, pp. 23-24; Jan., 1934.

Jackson, D. Orthogonal trigonometric sums. Read Aug. 30, 1932, and April 15, 1933. Annals of Mathematics, (2), vol. 34, No. 4, pp. 799-814; Oct., 1933.

Note on relations connecting certain cases of convergence in the mean. Read Dec. 27, 1933. This Bulletin, vol. 40, No. 2, pp. 152-158; Feb., 1934.

- The summation of series of orthogonal polynomials. Read April 7, 1934. This Bulletin, vol. 40, No. 10, pp. 743-752; Oct., 1934.

Jacobson, N. Non-commutative polynomials and cyclic algebras. Read June 19, 1933. Annals of Mathematics, (2), vol. 35, No. 2, pp. 197-210; April, 1934.

James, G. On the limit of an arc of a one parameter curve. Read Nov. 29, 1930. Tôhoku Mathematical Journal, vol. 39, No. 2, pp. 322-326; June, 1934.

— On Fermat's last theorem. Read Aug. 31, 1932. American Mathematical Monthly, vol. 41, No. 7, pp. 419-424; Aug.-Sept., 1934. 
James, R. D. The representation of integers as sums of pyramidal numbers. Read Feb. 25, 1933. Mathematische Annalen, vol. 109, No. 2, pp. 196-199; Dec., 1933.

The value of the number $g(k)$ in Waring's problem. Read March 18, 1933. Transactions of this Society, vol. 36, No. 2, pp. 395-444; April, 1934.

- On Waring's problem for odd powers. Read Dec. 27, 1932. Proceedings of the London Mathematical Society, (2), vol. 37, No. 4, pp. 257-291; May, 1934.

- The representation of integers as sums of values of cubic polynomials. Read April 7, 1934. American Journal of Mathematics, vol. 56, No. 3, pp. 303315 ; July, 1934.

- On the expansion coefficients of the functions $u / \mathrm{sn} u$ and $u^{2} / \mathrm{sn}^{2} u$. Read March 30, 1934. This Bulletin, vol. 40, No. 8, pp. 632-640; Aug., 1934.

Jeffery, R. L. Derived numbers with respect to functions of bounded variation. Read April 15, 1933. Transactions of this Society, vol. 36, No. 4, pp. 749758; Oct., 1934.

Jones, $\mathrm{B}$. W. The transformations effecting the reduction of positive quaternary quadratic forms. Read Dec. 28, 1931, Dec. 27, 1932, and Dec. 27, 1933. Annals of Mathematics, (2), vol. 35, No. 3, pp. 516-528; July, 1934.

Kaltenborn, H. S. Linear functional operations on functions having discontinuities of the first kind. Read April 6, 1934. This Bulletin, vol. 40, No. 10, pp. 702-708; Oct., 1934.

Kasner, E. General theorems on trajectories and lines of force. Read Oct. 30, 1909. Proceedings of the National Academy of Sciences, vol. 20, No. 2, pp. 130136; Feb., 1934.

- Dynamical trajectories and curvature trajectories. Read April 26, 1919. This Bulletin, vol. 40, No. 6, pp. 449-455; June, 1934.

Kellogg, O. D. Converses of Gauss' theorem on the arithmetic mean. Read June 23, 1933. Transactions of this Society, vol. 36, No. 2, pp. 227-242; April, 1934.

Kennison, L. S. Note on homogeneous functionals. Read March 25, 1932. This Bulletin, vol. 40, No. 2, pp. 80-83; Feb., 1934.

Ketchum, P. W. Expansions of two arbitrary analytic functions in a series of rational functions. Read April 15, 1933. Annals of Mathematics, (2), vol. 35, No. 4, pp. 759-775; Oct., 1934.

Kimball, B. F. Application of Bernoulli polynomials of negative order to differencing (second paper). Read April 14, 1933. American Journal of Mathematics, vol. 56, No. 1, pp. 147-152; Jan., 1934.

Koopman, B. O. See Brown, A. B.

Lane, E. P. The moving trihedron. Read April 7, 1934. Transactions of this Society, vol. 36, No. 3, pp. 696-710; July, 1934.

Langer, R. E. The asymptotic solutions of certain linear ordinary differential equations of the second order. Read Dec. 27, 1933. Transactions of this Society, vol. 36, No. 1, pp. 90-106; Jan., 1934.

- The asymptotic solutions of ordinary linear differential equations of the second order, with special reference to the Stokes phenomenon. Read April 6, 1934. This Bulletin, vol. 40, No. 8, pp. 545-582; June, 1934.

- The solutions of the Mathieu equation with a complex variable and at least 
one parameter large. Read April 6, 1934. Transactions of this Society, vol. 36, No. 3, pp. 637-695; July, 1934.

LaPaz, L. On a lemma of Fejêr. Read Dec. 2, 1933. This Bulletin, vol. 40, No. 12, pp. 904-907; Dec., 1934.

Laporte, O. On spinors and their significance in modern physics. Read Dec. 2, 1933. Physical Review, (2), vol. 45, No. 2, pp. 126-127; Jan., 1934.

Latimer, C. G. Note on the invariants of the class group of a cyclic field. Read June 23, 1933. Annals of Mathematics, (2), vol. 34, No. 4, pp. 872-874; Oct., 1933.

On the units in a cyclic field. Read Dec. 1, 1933. American Journal of Mathematics, vol. 56, No. 1, pp. 69-74; Jan., 1934.

On the finiteness of the class number in a semi-simple algebra. Read Dec. 27, 1933. This Bulletin, vol. 40, No. 6, pp. 433-435; June, 1934.

Lehmer, D. H. A photo-electric number sieve. Read Aug. 31, 1932. American Mathematical Monthly, vol. 40, No. 7, pp. 401-406; Aug.-Sept., 1933.

Lehmer, D. N. On the enumeration of magic cubes. Read June 20, 1934. This Bulletin, vol. 40, No. 12, pp. 833-837; Dec., 1934.

Levi-Civita, T. Terne di congruenze sopra una superficie ed estensione della trigonometria. Read June 21, 1933. Compositio Mathematica, vol. 1, No. 1, pp. 115-162; Jan. 25, 1934.

Levy, H. Curvatures in Riemannian space. Read Dec. 27, 1933. This Bulletin, vol. 40, No. 2, pp. 75-78; Feb., 1934.

- Linearly connected spaces and ennuples of curves. Read Dec. 27, 1933. American Journal of Mathematics, vol. 56, No. 3, pp. 381-395; July, 1934.

Lewis, D. C. On certain periodic motions of dynamical systems with more than two degrees of freedom. Read Dec. 27, 1933. American Journal of Mathematics, vol. 56, No. 1, pp. 25-41; Jan., 1934.

McCoy, N. H. On quasi-commutative matrices. Read Dec. 27, 1932. Transactions of this Society, vol. 36, No. 2, pp. 327-340; April, 1934.

- See Dines, L. L.

McFarlan, L. H. The problem of Lagrange of the calculus of variations for which the integrand contains the coordinates of the end points. Read June 20, 1930. Tôhoku Mathematical Journal, vol. 39, No. 1, pp. 66-81; April, 1934.

McShane, E. J. Integrals over surfaces in parametric form. Read Oct. 29, 1932. Annals of Mathematics, (2), vol. 34, No. 4, pp. 815-838; Oct., 1933.

— Existence theorems for ordinary problems of the calculus of variations. (Part I.) Read Oct. 28, 1933. Annali della Reale Scuola Normale Superiore di Pisa, (2), vol. 3, No. 2, pp. 183-211; March, 1934.

Concerning the semi-continuity of ordinary integrals of the calculus of variations. Read Oct. 28, 1933. Annali della Reale Scuola Normale Superiori di Pisa, (2), vol. 3, No. 2, pp. 239-241; March, 1934.

- The DuBois-Reymond relation in the calculus of variations. Read Oct. 28, 1933. Mathematische Annalen, vol. 109, No. 5, pp. 746-755; May, 1934. The analytic nature of surfaces of least area. Read Oct. 28, 1933. Annals of Mathematics, (2), vol. 35, No. 3, pp. 456-475; July, 1934.

- Existence theorems for ordinary problems of the calculus of variations. (Part II.) Read Oct. 28, 1933. Annali della Reale Scuola Normale Superiore di Pisa, (2), vol. 3, Nos. 3-4, pp. 287-315; Sept., 1934. 
- Extension of range of functions. Read June 20,1934. This Bulletin, vol. 40, No. 12, pp. 837-842; Dec., 1934.

MacColl, L. A. On the distributions of the zeros of sums of exponentials of polynomials. Read Oct. 29, 1932. Transactions of this Society, vol. 36, No. 2, pp. 341-360; April, 1934.

MacQueen, M. L. A projective generalization of metrically defined associate surfaces. Read Sept. 7, 1934. Transactions of this Society, vol. 36, No. 4, pp. 826-840; Oct., 1934.

Maier, W. Lamê's functions and Lucas' numbers. Read April 15, 1933. Jahresbericht der Deutschen Mathematiker-Vereinigung, vol. 43, Nos. 1-4, Abteilung II, p. 2, Aufgabe 155; 1933.

_- Integral equations and elliptic functions. Read Dec. 2 and Dec. 27, 1933. Jahresbericht der Deutschen Mathematiker-Vereinigung, vol. 43, Nos. o-12, Abteilung II, p. 114, Aufgabe 166; 1934.

Mayor, J. R. A generalization of the Veronese and Steiner surfaces. Read April 14, 1933. American Journal of Mathematics, vol. 56, No. 3, pp. 372-380; July, 1934.

Miller, G. A. Groups in which the squares of the elements are a dihedral subgroup. Read Sept. 7, 1934. Transactions of this Society, vol. 36, No. 4, pp. 819825 ; Oct., 1934.

Miller, W. I. Fundamental regions for the simple group of order 168 in $S_{4}$. Read June 19, 1933. American Journal of Mathematics, vol. 56, No. 3, pp. 316318; July, 1934.

Montgomery, D. A metrical property of point set transformations. Read March 30, 1934. This Bulletin, vol. 40, No. 8, pp. 620-624; Aug., 1934.

- Properties of plane sets and functions of two variables. Read Dec. 27, 1933, and March 31, 1934. American Journal of Mathematics, vol. 56, No. 4, pp. 569-586; Oct., 1934.

Moore, C. N. On criteria for Fourier constants of L-integrable functions. Read April 15, 1933. Proceedings of the National Academy of Sciences, vol. 19, No. 9, pp. 846-848; Sept., 1933.

Moore, R. L. Concerning compact continua which contain no continuum that separates the plane. Read Oct. 28, 1933. Proceedings of the National Academy of Sciences, vol. 20, No. 1, pp. 41-45; Jan., 1934.

Morrey, C. B. A class of representations of manifolds. Part II. Read Oct. 29, 1932. American Journal of Mathematics, vol. 56, No. 2, pp. 275-293; April, 1934.

Morse, M. Does instability imply transitivity? Read Dec. 27, 1933. Proceedings of the National Academy of Sciences, vol. 20, No. 1, pp. 46-50; Jan., 1934.

- The calculus of variations in the large. Read Sept. 8-11, 1931, and Dec. 29, 1932. American Mathematical Society Colloquium Publications, vol. $18,1934.10+368 \mathrm{pp}$.

Moursund, A. F. On the Nevanlinna and Bosanquet-Linfoot summation methods. Read Dec. 2, 1933. Annals of Mathematics, (2), vol. 35, No. 2, pp. 239247; April, 1934.

- On Nevanlinna's weak summation method. Read June 20, 1934. This Bulletin, vol. 40, No. 6, pp. 455-460; June, 1934. 
von Neumann, J. Almost periodic functions in a group. I. Read March 31, 1934. Transactions of this Society, vol. 36, No. 3, pp. 445-492; July, 1934.

Newton, A. V. Consecutive covariant configurations at a point of a space curve. Read June 22, 1933. Transactions of this Society, vol. 36, No. 1, pp. 4462; Jan., 1934.

Northrop, E. P. Note on a singular integral. Read Dec. 26, 1933. This Bulletin, vol. 40, No. 6, pp. 494-496; June, 1934.

Oldenburger, R. Transposition of indices in multiple-labeled determinants. Read March 30, 1934. American Mathematical Monthly, vol. 41, No. 6, pp. 350-356; June-July, 1934.

- Composition and rank of $n$-way matrices and multilinear forms. Read Dec. 30, 1930, and April 3, 1931. Annals of Mathematics, (2), vol. 35, No. 3, pp. 622-653; July, 1934.

- Composition and rank of n-way matrices and multilinear forms-supplement. Read April 7, 1934. Annals of Mathematics, (2), vol. 35, No. 3, pp. 654-657; July, 1934.

Ore, O. Contributions to the theory of finite fields. Read Oct. 28, 1933. Transactions of this Society, vol. 36, No. 2, pp. 243-274; April, 1934.

Paley, R. E. A. C., and Wiener, N. Fourier transforms in the complex domain. Read Sept. 4-7, 1934. American Mathematical Society Colloquium Publications, vol. 19, 1934. 8+184 pp.

Parker, W. V. On symmetric determinants. Read Oct. 28, 1933. American Mathematical Monthly, vol. 41, No. 3, pp. 174-178; March, 1934.

Perlo, V. On the distribution of Student's ratio for samples of three drawn from a rectangular distribution. Read Oct. 29, 1932. Biometrika, vol. 25, Nos. 1-2, pp. 203-204; May, 1933.

Peterson, T. S. Note on the law of transformation of the nth resolvent. Read March 29, 1929. Tôhoku Mathematical Journal, vol. 39, No. 2, pp. 347354; June, 1934.

Poor, V. C. On the theory of residues of polygenic functions. Read Dec. 27, 1933. This Bulletin, vol. 40, No. 12, pp. 877-883; Dec., 1934.

Rashevsky, N. Foundations of mathematical biophysics. Read Sept. 12, 1930. Philosophy of Science, vol. 1, No. 2, pp. 176-196; April, 1934.

Raudenbush, H. W. Ideal theory and algebraic differential equations. Read Oct. 28 and Dec. 27, 1933. Transactions of this Society, vol. 36, No. 2, pp. 361-368; April, 1934.

- Hypertranscendental extensions of partial differential fields. Read March 31, 1934. This Bulletin, vol. 40, No. 10, pp. 714-720; Oct., 1934.

Regan, F. The application of the theory of admissible numbers to time series with constant probability. Read April 15, 1933. Transactions of this Society, vol. 36, No. 3, pp. 511-529; July, 1934.

Reid, W. T. Analogues of the Jacobi condition for the problem of Mayer in the calculus of variations. Read Dec. 29, 1932. Annals of Mathematics, (2), vol. 35, No. 4, pp. 836-848; Oct., 1934.

Ritt, J. F. Algebraic difference equations. Read March 31, 1934. This Bulletin, vol. 40, No. 4, pp. 303-308; April, 1934.

Roberts, J. H. On a problem of Knaster and Zarankiewicz. Read Dec. 1, 1933. This Bulletin, vol. 40, No. 4, pp. 281-283; April, 1934. 
Robinson, L. B. Sur une équation aux différences mêlées. Read Oct. 28, 1933. Archives du Congrès de Chambéry, 1933.

Robinson, S. An experiment regarding the $\chi^{2}$ test. Read April 14, 1933. Annals of Mathematical Statistics, vol. 4, No. 4, pp. 285-287; Nov., 1933.

Rosskopf, M. F. Some inequalities for non-uniformly bounded ortho-normal polynomials. Read Dec. 27, 1933. Transactions of this Society, vol. 36, No. 4, pp. 853-867; Oct., 1934.

Roth, W. E. On direct product matrices. Read April 6, 1934. This Bulletin, vol. 40, No. 6, pp. 461-468; June, 1934.

Russell, H. G., and Walsh, J. L. On the convergence and overconvergence of sequences of polynomials of best simultaneous approximation to several functions analytic in distinct regions. Read Oct. 29, 1932. Transactions of this Society, vol. 36, No. 1, pp. 13-28; Jan., 1934.

Rust, W. M. A theorem on Volterra integral equations of the second kind with discontinuous kernels. Read Oct. 29, 1932. American Mathematical Monthly, vol. 41, No. 6, pp. 346-350; June-July, 1934.

Rutt, N. E. Some theorems. on triodic continua. Read June 22, 1933. American Journal of Mathematics, vol. 56, No. 1, pp. 122-132; Jan., 1934.

Schmeiser, M. Some properties of arbitrary functions. Read Dec. 26, 1933. Fundamenta Mathematicae, vol. 22, pp. 70-76; 1934.

Schoenberg, I. J. Zur Abzählung der reellen Wurzeln algebraischer Gleichungen. Read April 14, 1933. Mathematische Zeitschrift, vol. 38, No. 4, pp. 546564; May, 1934.

Schwatt, I. J. The sum of like powers of a series of numbers forming an arithmetical progression and the Bernoulli numbers. Read June 19, 1933. Matematicheski Sbornik, vol.39, No.4, pp.134-140; 1932 (published in 1933).

Seidel, W. On the distribution of values of bounded analytic functions. Read Oct. 29, 1932. Transactions of this Society, vol. 36, No. 1, pp. 201-226; Jan., 1934.

Sharpe, F. R. See Dye, L. A.

Sheffer, I. M. An aspect of the theory of linear differential equations. Read Dec. 29, 1932. Tôhoku Mathematical Journal, vol. 39, No. 2, pp. 299-315; June, 1934.

Shohat, J. A., and Winston, C. On mechanical quadratures. Read June 23, 1933. Rendiconti del Circolo Matematico di Palermo, vol. 58, Nos. 1-2, pp. 153-160, 161-165; Jan.-April, May-Aug., 1934.

Simmons, H. A. The first and second variations of an $n$-tuple integral in the case of variable limits. Read Dec. 1, 1933. Transactions of this Society, vol. 36, No. 1, pp. 29-43; Jan., 1934.

Simmons, H. A., and Stelford, N. Classes of maximum numbers associated with certain symmetric equations in $n$ reciprocals. Read April 6, 1934. This Bulletin, vol. 40, No. 12, pp. 884-894; Dec., 1934.

Smith, A. H. On the summability of derived conjugate series of the FourierLebesgue type. Read Oct. 28, 1933. This Bulletin, vol. 40, No. 6, pp. 406412; June, 1934.

Smith, P. A. A theorem on fixed points for periodic transformations. Read Dec. 27, 1933. Annals of Mathematics, (2), vol. 35, No. 3, pp. 572-578; July, 1934. 
Snyder, V. Some recent contributions to algebraic geometry. Read March 30, 1934. This Bulletin, vol. 40, No. 10, pp. 673-687; Oct., 1934.

See Clarkson, J. M.

Sokolnikoff, E. S., and Sokolnikoff, I. S. Note on a resolution of linear differential systems. Read April 14, 1933. Proceedings of the Edinburgh Mathematical Society, (2), vol. 4, No. 1, pp. 36-40; March, 1934.

Sokolnikoff, I. S. See Sokolnikoff, E. S.

Sperner, E. Über die fixpunktfreie Abbildungen der Ebene. Read Sept. 2, 1932. Hamburger Mathematische Einzelschriften, No. 14, 1933. 47 pp.

Steenrod, N. E. Characterizations of certain finite curve-sums. Read Dec. 27, 1933. American Journal of Mathematics, vol. 56, No.4, pp. 558-568; Oct., 1934.

_ Finite arc-sums. Read April 14, 1933. Fundamenta Mathematicae, vol. 23 , pp. 38-53; 1934 .

Stelford, N. See Simmons, H. A.

Stephens, R. Note on a problem of Fréchet. Read Oct. 28, 1933. This Bulletin, vol. 40, No. 2, pp. 65-68; Feb., 1934.

— Continuous transformations of finite spaces. Read Sept. 2, 1932. Tôhoku Mathematical Journal, vol. 39, No. 1, pp. 98-106; April, 1934.

Stone, M. H. Boolean algebras and their applications to topology. Read Feb. 25, 1933. Proceedings of the National Academy of Sciences, vol. 20, No. 3, pp. 197-202; March, 1934.

Synge, J. L. On the deviation of geodesics and null-geodesics, particularly in relation to the properties of spaces of constant curvature and indefinite line-element. Read Dec. 27, 1933. Annals of Mathematics, (2), vol. 35, No. 4, pp. 705-713; Oct., 1934.

Tamarkin, J. D. See Hille, E.

Taylor, A. E. On integral invariants of non-holonomic dynamical systems. Read June 20, 1934. This Bulletin, vol. 40, No. 10, pp. 735-742; Oct., 1934.

Thielman, H. P. On the invariance of a generalized Gramian in a Riemannian function space. Read April 13, 1933. American Journal of Mathematics, vol. 56, No. 3, pp. 438-444; July, 1934.

Note on the use of fractional integration of Bessel functions. Read April 7, 1934. This Bulletin, vol. 40, No. 10, pp. 695-698; Oct., 1934.

Thomas, J. M. A lower limit for the species of a Pfaffian system. Read Oct. 28, 1933. Proceedings of the National Academy of Sciences, vol. 19, No. 10, pp. 913-914; Oct., 1933.

- Riquier's existence theorems. Read Nov. 28, 1931. Annals of Mathematics, (2), vol. 35, No. 2, pp. 306-311; April, 1934.

-An existence theorem for generalized Pfaffian systems. Read Dec. 1, 1933. This Bulletin, vol. 40, No. 4, pp. 309-315; April, 1934.

- The condition for a Pfaffian system in involution. Read Dec. 1, 1933. This Bulletin, vol. 40, No. 4, pp. 316-320; April, 1934.

Titt, E. W. Cauchy's problem for systems of second order partial differential equations. Read June 23, 1933. Annals of Mathematics, (2), vol. 35, No. 1, pp. 162-184; Jan., 1934.

Trjitzinsky, W. J. A nalytic theory of linear differential equations. Read Dec. 27, 1933. Acta Mathematica, vol. 62, Nos. 1-2, pp. 167-226; 1933. 
Uspensky, J. V. On an expansion of the remainder in the Gaussian quadrature formula. Read June 20, 1934. This Bulletin, vol. 40, No. 12, pp. 871-876; Dec., 1934.

Vanderslice, J. L. Non-holonomic geometries. Read Oct. 28, 1933. American Journal of Mathematics, vol. 56, No. 2, pp. 153-193; April, 1934.

Vandiver, H. S. Fermat's last theorem and the second factor in the cyclotomic class number. Read June 19, 1933. This Bulletin, vol. 40, No. 2, pp. 118-126; Feb., 1934.

Veblen, O. Spinors in projective relativity. Read Dec. 2, 1933. Proceedings of the National Academy of Sciences, vol. 19, No. 11, pp. 979-989; Nov., 1933;

Wall, H. S. Continued fractions and cross-ratio groups of Cremona transformations. Read April 6, 1934. This Bulletin, vol. 40, No. 8, pp. 587-592; Aug., 1934.

Walsh, J. L. On series of interpolation and the degree of convergence of sequences of analytic functions. Read March 25, 1932. Tôhoku Mathematical Journal, vol. 38 (Second Memorial Volume dedicated to T. Hayashi), pp. 375389; Nov., 1933.

- On approximation to an analytic function by rational functions of best approximation. Read Oct. 29, 1932. Mathematische Zeitschrift, vol. 38, No. 2, pp. 163-176; Jan., 1934.

- Note on the orthogonality of Tchebycheff polynomials on confocal ellipses. Read Oct. 28, 1933. This Bulletin, vol. 40, No. 2, pp. 84-88; Feb., 1934.

- See Russell, H. G.

Ward, M. Note on the iteration of functions of one variable. Read June 20, 1934. This Bulletin, vol. 40, No. 10, pp. 688-690; Oct., 1934.

- An arithmetical property of recurring series of the second order. Read June 20, 1934. This Bulletin, vol. 40, No. 12, pp. 825-828; Dec., 1934.

Webber, G. C. Waring's problem for cubic functions. Read April 6, 1934. Transactions of this Society, vol. 40, No. 3, pp. 493-510; July, 1934.

Weisner, L. Criteria for the irreducibility of polynomials. Read March 30, 1934. This Bulletin, vol. 40, No. 12, pp. 864-870; Dec., 1934.

Weiss, M. J. On simply transitive primitive groups. Read Dec. 27, 1933. This Bulletin, vol. 40, No. 6, pp. 401-405; June, 1934.

White, H. S. The construction of a headless and groupless triad system on 31 elements. Read Sept. 11, 1930. This Bulletin, vol. 40, No. 12, pp. 829-832; Dec., 1934.

Whitney, H. Planar graphs. Read Dec. 28, 1931. Fundamenta Mathematicae, vol. 21, pp. 73-84; 1933.

- Analytic extensions of differentiable functions defined in closed sets. Read Dec. 29, 1932. Transactions of this Society, vol. 36, No. 1, pp. 63-89; Jan., 1934.

—Derivatives, difference quotients, and Taylor's formula. Read June 23, 1933. This Bulletin, vol. 40, No. 2, pp. 89-94; Feb., 1934.

- Differentiable functions defined in closed sets. I. Read Oct. 28, 1933. Transactions of this Society, vol. 36, No. 2, pp. 369-387; April, 1934.

- Derivatives, difference quotients, and Taylor's formula. II. Read Dec. 27, 1933. Annals of Mathematics, (2), vol. 35, No. 3, pp. 476-481; July, 1934. 
- Functions differentiable on the boundaries of régions. Read Dec. 27, 1933. Annals of Mathematics, (2), vol. 35, No. 3, pp. 482-485; July, 1934.

Whyburn, G. T. Cyclic elements of higher orders. Read Dec. 27, 1933. American Journal of Mathematics, vol. 56, No. 1, pp. 133-146; Jan., 1934.

—Concerning maximal sets. Read Oct. 28, 1933. This Bulletin, vol.40, No. 2, pp. 159-164; Feb., 1934.

- Non-alternating transformations. Read March 30, 1934. American Journal of Mathematics, vol. 56, No. 2, pp. 294-302; April, 1934.

Whyburn, W. M. Generalized Riccati differential equations. Read Nov. 29, 1929. Tôhoku Mathematical Journal, vol. 38 (Second Memorial Volume dedicated to T. Hayashi), pp. 447-450; Nov., 1933.

- Matrix differential systems. Read Dec. 2, 1933. American Journal of Mathematics, vol. 56, No. 4, pp. 587-592; Oct., 1934.

Widder, D. V. The inversion of the Laplace integral and the related moment problem. Read Dec. 29, 1932. Transactions of this Society, vol. 36, No. 1, pp. 107-200; Jan., 1934.

- Necessary and sufficient conditions for the representation of a function by a doubly infinite Laplace integral. Read Dec. 27, 1933. This Bulletin, vol.40, No. 4, pp. 321-326; April, 1934.

Wiener, N. See Paley, R. E. A. C.

Wilder, R. L. Concerning a problem of K. Borsuk. Read Oct. 28, 1933. Fundamenta Mathematicae, vol. 21, pp. 156-167; 1933.

On the properties of domains and their boundaries in $E_{n}$. Read Sept. 9, 1930, June 13, 1931, and Sept. 8, 1931. Mathematische Annalen, vol. 109, No. 2, pp. 273-306; Dec., 1933.

- Concerning irreducibly connected sets and irreducible regular connexes. Read April 7, 1928. American Journal of Mathematics, vol. 56, No. 4, pp. 547557; Oct., 1934.

- Generalized closed manifolds in n-space. Read Dec. 27, 1933, and March 30, 1934. Annals of Mathematics, (2), vol. 35, No. 4, pp. 876-903; Oct., 1934.

Williams, A. R. The apparent contour of the general $V_{3}^{n}$ in $S_{4}$. Read Dec. 2, 1933. This Bulletin, vol. 40, No. 2, pp. 103-110; Feb., 1934.

Williamson, J. The covariants of two quadratic forms in $n$ variables. Read March 30, 1934. American Journal of Mathematics, vol. 56, No. 3, pp. 339-348; July, 1934.

Winston, C. On the mechanical quadratures formulae involving the classical orthogonal polynomials. Read April 14, 1933. Annals of Mathematics, (2), vol. 35, No. 3, pp. 658-677; July, 1934.

See Shohat, J. A.

Wong, B. C. A hypersurface of order $2^{r-1}$ in r-space. Read June 21, 1929. American Journal of Mathematics, vol. 54, No. 2, pp. 293-298; April, 1932.

- Enumerative properties of $r$-space curves. Read Nov. 28, 1931. This Bulletin, vol. 40, No. 4, pp. 291-296; April, 1934.

- Loci of $m$-spaces joining corresponding points of $m+1$ projectively related $n$-spaces in r-space. Read June 20, 1934. This Bulletin, vol. 40, No. 12, pp. 850-854; Dec., 1934.

Zygmund, A. Some points in the theory of trigonometric and power series. Read March 31, 1934. Transactions of this Society, vol. 36, No. 3, pp. 586-617; July, 1934. 